\begin{tabular}{|c|c|c|c|c|}
\hline Share: Social Work Jurnal & VOLUME: 9 & NOMOR: 1 & HALAMAN: 10-19 & $\begin{array}{c}\text { ISSN:2339-0042 (p) } \\
\text { ISSN: 2528-1577 }(e) \\
\text { Doi: 10.24198/share.v9i1.19691 }\end{array}$ \\
\hline
\end{tabular}

\title{
Gender dan Stereotipe: Konstruksi Realitas dalam Media Sosial I nstagram
}

\author{
Feryna Nur Rosyidah ${ }^{1}$, Nunung Nurwati ${ }^{2}$ \\ 1. Pascasarjana Sosiologi, Fakultas IImu Sosial dan IImu Politik, Universitas Padjaradjaran \\ ferynanurr@gmail.com \\ 2. Program Studi Kesejahteraan Sosial, Fakultas IImu Sosial dan IImu Politik, Universitas Padjadjaran \\ nngnurwati@yahoo.co.id
}

\begin{abstract}
ABSTRAK
Artikel ini berfokus pada permasalahan gender dan stereotipe khususnya dalam hal konstruksi realitas sosial yang terjadi dalam media sosial Instagram. Pendekatan kualitatif dengan metode etnografi virtual yang dilakukan untuk melihat fenomena sosial dan kultur pengguna di ruang siber. Fokus kajian dalam artikel ini adalah membahas; (1) konstruksi realitas dalam media sosial, dan (2) hubungan antara gender dan stereotipe yang terjadi dalam ruang media sosial Instagram. Informasi yang berkembang dalam media sosial telah menciptakan suatu area tanpa batas yuridiksi, sehingga interaksi yang terjadi juga telah menciptakan suatu hubungan tanpa batas. Media sosial menjadi salah satu sarana bagi masyarakat untuk mengumpulkan kepercayaan diri serta dukungan dari lingkungannya, memudahkan mereka dan meningkatkan rasa ingin tahu akan dunia yang lebih luas, serta dijadikan sebagai sarana untuk memuaskan hasrat baik yang bersifat positif maupun negatif yang tidak dapat mereka lakukan di dunia nyata. Pada penggunaan media sosial ini ternyata gender adalah satu-satunya variabel demografi yang sangat signifikan berpengaruh dalam penggunaan media sosial, karena ada beberapa perbedaan antara pengguna media sosial laki-laki dan perempuan. Dapat disimpulkan bahwa dalam hal perubahan ini, telah terjadi pembentukan identitas yang di rekonfigurasi ruang dan waktu yang terikat dengan teknologi baru.

Kata Kunci: Gender, Stereotipe, Realitas Sosial, Media Sosial, Instagram
\end{abstract}

\begin{abstract}
This article focuses on issues of gender and stereotypes especially in terms of the construction of social realities that occur on Instagram social media. A qualitative approach with virtual eth $n$ ographic methods is carried out to see the social phenomena and culture of users in cyberspace. The focus of the study in this article is to discuss; (1) the construction of reality in social media, and (2) the relationship between gender and stereotypes that occur in the social media space of Instagram. Information that develops in social media has created an area without boundary jurisdiction, so that the interaction that occurs has also created a relationship without limits. Social media is one means for the community to gather confidence and support from the environment, facilitate them and increase the curiosity of the wider world, and serve as a means to satisfy both positive and negative desires that they cannot do in the world real. In the use of social media it turns out that gender is the only demographic variable that is very significantly influential in the use of social media, because there are several differences between male and female social media users. It can be concluded that in terms of this change, there has been a formation of identities that are reconfigured by space and time that are tied to new technology.
\end{abstract}

Keywords: Gender, Stereotypes, Social Reality, Social Media, Instagram

\section{Pendahuluan}

Pada dasarnya semua orang sepakat bahwa perempuan dan laki-laki berbeda. Pembedaan yang terbentuk dalam masyarakat tidak terjadi secara alamiah, akan tetapi terkonstruksi sudah sejak lama. Setiadi (2011) mengatakan bahwa terdapat perbedaan mendasar antara gender dan jenis kelamin (seks), jenis kelamin lebih mengarah pada pembagian fisiologi atau anatomi manusia secara biologis. Adapun konsep gender 


\begin{tabular}{|c|c|c|c|c|}
\hline Share: Social Work Jurnal & VOLUME: 9 & NOMOR: 1 & HALAMAN: 10-19 & $\begin{array}{c}\text { ISSN:2339-0042 (p) } \\
\text { ISSN: 2528-1577 }(e) \\
\text { Doi: 10.24198/share.v9i1.19691 }\end{array}$ \\
\hline
\end{tabular}

merupakan istilah yang digunakan untuk membedakan antara laki-laki dan perempuan yang didasarkan pada aspek sosiokultural, gender merupakan atribut dan perilaku yang terbentuk melalui proses sosial. Adanya pelabelan terhadap pihak-pihak tertentu muncul sebagai akibat adanya pembedaan dalam konsep gender. Peran gender memberikan warna dan pengaruh dalam menentukan penggunaan satu obyek atau material tertentu.

Revolusi industri yang memunculkan teknologi-teknologi baru menguatkan pembagian kerja secara seksual. Interseksionalitas antar gender dan teknologi dapat dilihat dengan banyaknya perempuan dan laki-laki yang memanfaatkan teknologi dan mendapatkan manfaat dari teknologi tersebut. Hubungan yang telah terbentuk bukanlah hubungan yang baku, kaku dan statis, tetapi hubungan yang bisa berubah dan diubah. Stereotype perempuan dengan segala feminitasnya dan penggunaan perasaan ketimbang rasio menjadi salah satu hal yang dijadikan untuk mematahkan semangat perempuan dalam lingkup ilmu pengetahuan.

Media sosial adalah dalah satu bentuk perkembangan ilmu pengetahuan dan teknologi dalam bidang komunikasi. Tanpa memerlukan keahlian khusus, memanfaatkan media sosial menjadi sangat mudah (user friendly). Hampir semua kalangan masyarakat menjadi pengguna dari beberapa platform media sosial yang terus menerus bermunculan dan memiliki keunggulan serta fungsi yang berbeda satu sama lain. Media sosial digunakan para remaja untuk berlombalomba menjadikan identitas dirinya sebagai remaja yang "up to date” dengan cara menjadi pengguna aktif sosial media dengan check in place di tempat-tempat yang high class, foto-foto bersama teman-teman, genre music, film dan buku yang sedang popular. Berdasarkan pandangan Schutz, tindakan sosial dapat dipahami melalui penafsiran untuk memperjelas atau memeriksa makna yang sesungguhnya, sehingga dapat memberikan konsep kepekaan yang implisit. Proses pemahaman aktual kita, dan pemberian makna terhadapnya, sehingga terrefleksi dalam tingkah laku (dalam Kuswarno, 2009: 18). Semua tingkah laku manusia pada hakikatnya memiliki motif. Motif-motif ini memberi tujuan dan arah kepada tingkah laku manusia. Menyangkut motif, Schutz (dalam Kuswarno, 2009: 111) membaginya menjadi dua, yaitu: tindakan sosial merupakan tindakan yang berorientasi pada perilaku orang atau orang lain pada masa lalu (because motif), dan sekarang atau akan datang (in-order-to).

Instagram merupakan salah satu platform media sosial yang paling populer dan sedang digemari masyarakat saat ini. Terdapat lebiih dari 45 juta pengguna aktif Instagram di Indonesia setiap bulannya. Kata Instagram berasal dari kata "insta” yang berarti "instan” dan "gram” yang mempunyai arti “telegram”. Berdasarkan kedua kata tersebut, Instagram dapat diartikan menampilkan dan menyampaikan informasi berupa foto atau ambar secara cepat lewat aplikasi yang dapat diakses oleh orang lain. Instagram adalah sebuah aplikasi berbagi foto dan video yang memungkinkan pengguna mengambil foto atau video, menerapkan filter digital, dan membagikannya ke berbagai layanan jejaring sosial, termasuk milik Instagram sendiri.

Berangkat dari latar belakang tersebut, artikel ini bertujuan untuk menjelaskan konstruksi realitas yang terjadi dalam media sosial Instagram, serta hubungan antara gender dan stereotipe yang terjadi dalam ruang media sosial Instagram.

\section{Metode}

Kajian ini menggunakan pendekatan kualitatif. Penelitian ini dilakukan dengan studi etnografi virtual. Studi etnografi virtual merupakan metode etnografi yang dilakukan untuk melihat fenomena sosial dan kultur pengguna di ruang siber. Sebagai sebuah kultur dan artefak kultural, cyberspace atau dunia siber bagi peneliti etnografi virtual bisa mendekati beberapa objek atau fenomena yang ada di internet (Nasrullah dalam Nugraha, 2015, hlm. 240). Metode yang digunakan bertujuan untuk mengungkapkan kondisi penggunaan media sosial serta dampaknya di kalangan pelajar.

Penelitian dilakukan pada kondisi objek yang alami, peneliti sebagai instrumen kunci, teknik pengumpulan data dilakukan dengan studi dokumentasi, data yang dihasilkan bersifat deskriptif, analisis data dilakukan secara induktif, dan penelitian ini lebih menekankan makna 


\begin{tabular}{|c|c|c|c|c|}
\hline Share: Social Work Jurnal & VOLUME: 9 & NOMOR: 1 & HALAMAN: 10-19 & $\begin{array}{c}\text { ISSN:2339-0042 (p) } \\
\text { ISSN: 2528-1577 }(e) \\
\text { Doi: 10.24198/share.v9i1.19691 }\end{array}$ \\
\hline
\end{tabular}

daripada generalisasi (Sedarmayanti dan Hidayat, 2011, hlm. 33). Peneliti mengumpulkan data awal dengan cara menganalisis beberapa dokumen terkait permasalaha penelitian yang berfungsi sebagai dasar bagi peneliti terkait konstruksi realitas dalam media sosial Instagram. Adapun sumber data yang digunakan dalam penelitian ini adalah beberapa dokumen tentang penggunaan media sosial secara global. Analisis data dalam penelitian ini dilakukan dengan mengabstraksi beberapa data yang telah didapat dan dikumpulkan serta dikelompokkan.

\section{Hasil dan Pembahasan}

\section{Gender dan Stereotipe}

Gender dapat didefinisikan sebagai keadaan dimana individu yang lahir secara biologis sebagai laki-laki dan perempuan yang kemudian memperoleh pencirian sosial sebagai laki-laki dan perempuan melalui atribut-atribut maskulinitas dan feminitas yang sering didukung oleh nilainilai atau sistem dan simbol di masyarakat yang bersangkutan. Istilah gender seringkali tumpang tindih dengan seks (jenis kelamin), padahal dua kata tersebut memiliki makna yang berbedad. Seks merupakan pensifatan atau pembagian dua jenis kelamin manusia yang ditentukan secara biologis yang melekat pada jenis kelamin tertentu.

Secara etimologis kata 'gender' berasal dari bahasa Inggris yang berarti 'jenis kelamin' (dalam Echols \& Shadily, 1983, hlm. 265). Kata 'gender' bisa diartikan sebagai 'perbedaan yang tampak antara laki-laki dan perempuan dalam hal nilai dan perilaku (dalam Neufeldt, 1984, hlm. 561). Secara terminologis, 'gender' bisa didefinisikan sebagai harapan-harapan budaya terhadap lakilaki dan perempuan (dalam Lips, 1993 hlm. 4). Definisi lain tentang gender dikemukakan oleh Elaine Showalter. Menurutnya, 'gender' adalah pembedaan laki-laki dan perempuan dilihat dari konstruksi sosial budaya (dalam Showalter, 1989, hlm. 3). Gender bisa juga dijadikan sebagai konsep analisis yang dapat digunakan untuk menjelaskan sesuatu (dalam Umar, 1999, hlm. 34). Lebih tegas lagi disebutkan dalam Women's Studies Encyclopedia bahwa gender adalah suatu konsep kultural yang dipakai untuk membedakan peran, perilaku, mentalitas, dan karakteristik emosional antara laki-laki dan perempuan yang berkembang dalam masyarakat (dalam Mulia, 2004, hlm. 4).

Martin, Ruble, \& Szkrybalo (2002, hlm. 67) menyatakan bahwa menurut teori kognitif sosial, gender berkembang melalui mekanisme yang terdiri atas observasi, imitasi, penghargaan, dan hukuman. Menurut pandangan kognitif interaksi antara anak dan lingkungan sosial merupakan kunci utama untuk perkembangan gender. Menurut Santrock (2009, hlm. 232) beberapa pengkritik berpendapat bahwa penjelasan ini kurang memperhatikan pikiran dan pemahaman anak, serta menggambarkan bahwa anak menerima peran gender secara pasif, serta gender dan seks memiliki perbedaan dari segi dimensi. Isilah seks (jenis kelamin) mengacu pada dimensi biologis seorang laki-laki dan perempuan, sedangkan gender mengacu pada dimensi sosialbudaya seorang laki-laki dan perempuan.

Gender diartikan sebagai konstruksi sosiokultural yang membedakan karakteristik maskulin dan feminim. Istilah gender dikemukakan oleh para ilmuwan sosial dengan maksud untuk menjelaskan perbedaan perempuan dan laki-laki yang mempunyai sifat bawaan dan bentukan budaya. Gender adalah perbedaan peran, fungsi, dan tanggungjawab antara laki-laki dan perempuan yang merupakan hasil konstruksi sosial dan dapat berubah sesuai dengan perkembangan jaman.

Dari beberapa definisi di atas dapat dipahami bahwa gender adalah suatu sifat yang dijadikan dasar untuk mengidentifikasi perbedaan antara laki-laki dan perempuan dilihat dari segi kondisi sosial dan budaya, nilai dan perilaku, mentalitas, dan emosi, serta faktor-faktor nonbiologis lainnya. Gender berbeda dengan sex, meskipun secara etimologis artinya sama sama dengan sex, yaitu jenis kelamin (Echols dan Shadily, 1983, hlm. 517).

Sejarah perbedaan gender antara seorang pria dengan seorang wanita terjadi melalui proses yang sangat panjang dan dibentuk oleh beberapa sebab, seperti kondisi sosial budaya, kondisi keagamaan, dan kondisi kenegaraan. Dengan proses yang panjang ini, perbedaan gender akhirnya sering dianggap menjadi ketentuan Tuhan yang bersifat kodrati atau seolah-olah bersifat biologis yang tidak dapat diubah lagi. Inilah sebenarnya yang menyebabkan awal 


\begin{tabular}{|c|c|c|c|c|}
\hline Share: Social Work Jurnal & VOLUME: 9 & NOMOR: 1 & HALAMAN: 10-19 & $\begin{array}{c}\text { ISSN:2339-0042 (p) } \\
\text { ISSN: 2528-1577 }(e) \\
\text { Doi: 10.24198/share.v9i1.19691 }\end{array}$ \\
\hline
\end{tabular}

terjadinya ketidakadilan gender di tengah-tengah masyarakat.

Salah satu jenis stereotype bersumber dari pandangan gender. Banyak sekali ketidakadilan terhadap jenis kelamin yang bersumber dari pendangan (streotype) yang dilekatkan pada mereka. Ada berbagai cara untuk memandang perkembangan gender. Beberapa menekankan faktor biologis dalam perilaku laki-laki dan perempuan yang lain menekankan faktor sosial atau kognitif (Lippa, 2005, hlm. 47). Menurut LeDoux (dalam Santrock, 2009, hlm. 220) pendekatan biologis menjelaskan perbedaan dalam otak perempuan dan laki-laki. Satu pendekatan berfokus pada perbedaan antara perempuan dan laki-laki di dalam corpus collosum, sekumpulan sel saraf yang menggabungkan dua belahan otak. Corpus collosum pada perempuan lebih besar daripada pada laki-laki dan ini menjelaskan mengapa perempuan lebih sadar dibandingkan dengan lakilaki tentang emosi mereka sendiri dan emosi orang lain (Santrock, 2009, hlm. 221). Ini terjadi karena otak kanan mampu meneruskan lebih banyak informasi tentang emosi ke otak kiri. Bagian otak yang terlibat dalam pengungkapan emosional menunjukkan lebih banyak aktivitas metabolis pada perempuan dibandingkan pada laki-laki. Selain itu, bagian lobus parietal (salah satu cuping otak di bagian ujung kepala) yang berfungsi dalam keterampilan visual dan ruang pada laki-laki, lebih besar daripada perempuan (Frederikse et.al, 2000, hlm. 147).

Stereotype sering kali negatif dan bisa dikemas dalam prasangka dan diskriminasi. Seksisme (sexism) adalah prasangka dan diskriminasi terhadap satu individu karena jenis kelamin seseorang. Seseorang yang mengatakan bahwa wanita tidak bisa menjadi insinyur yang kompeten, sedang mengungkapkan seksisme. Begitu pula seseorang yang mengatakan bahwa pria tidak bisa menjadi guru anak-anak yang kompeten. Kontroversi Gender mengungkapkan beberapa perbedaan substansial dalam kemampuan fisik, keterampilan membaca dan menulis, agresi, dan pengaturan diri, hanya ada sedikit perbedaan dalam kemampuan matematika, dan ilmu pengetahuan. Buss (2007, hlm. 505) berpendapat bahwa perbedaan gender itu luas dan disebabkan oleh masalah-masalah adaptif yang dihadapi sepanjang sejarah evolusioner. Dalam tinjauan terkini, menemukan hasil dari 44 metaanalisis perbedaan dan persamaan gender. Sebagian besar bidang, termasuk kemampuan matematika, komunikasi, dan agresi, ditemukan sedikit perbedaan gender. Perbedaan terbesar muncul pada keterampilan motorik dan agresi fisik (pria lebih agresif secara fisik daripada wanita) (Hyde, 2005, hlm. 586).

Ketidakberdayaan perempuan adalah sebagai akibat dari konstruksi sosial yang selama ini menempatkan perempuan pada kedudukan yang subordinat, memberikan nilai yang kurang berarti bagi apa yang dikerjakannya. Stereotype perempuan dengan segala feminitasnya dan penggunaan perasaan ketimbang rasio menjadi salah satu paling diunggulkan untuk mematahkan semangat perempuan dalam ilmu pengetahuan. Ilmu eksakta yang mementingkan rasionalitas dijauhkan dari perempuan. Perempuan dipaksa untuk lebih tertarik pada ilmu sosial dan urusan domestik. Semua ini tidak terlepas dari konstruksi kerja berdasarkan jenis kelamin (sex based division of labor) (Saguni, 2014, hlm. 196). Di bidang reproduksi, ketidakberdayaan itu terlihat dari hubungan yang tidak berimbang antara lakilaki dan perempuan dalam hal seksual dan reproduksi, seperti tercermin dalam kasus pemaksaan hubungan kelamin, pemerkosaan, istri/perempuan yang berisiko tinggi terkena HIVAIDS, dan penyakit-penyakit lain yang ditularkan melalui hubungan seksual sebagai akibat dari kehamilan yang tidak diinginkan, bahkan bermacam-macam cara berkeluarga berencana hampir seluruhnya ditujukan untuk perempuan.

Berdasarkan uraian tersebut, stereotype merupakan generalisasi dari kelompok kepada orang-orang di dalam kelompok. Stereotype adalah pemberian sifat tertentu terhadap sesorang berdasarkan kategori yang bersifat subjektif hanya karena dia berasal dari kelompok lain. Stereotype didasarkan pada penafsiran yang kita hasilkan atas dasar cara pandang dan latar belakang budaya. Dekonstruksi sosial dan reorientasi diperlukan untuk merubah pemahaman hubungan gender seperti yang selama ini disosialisasikan. Orientasi baru dalam pemahaman hubungan gender yang harus disosialisasikan secara luas adalah hubungan gender yang seimbang dan harmonis, hubungan 


\begin{tabular}{|c|c|c|c|c|}
\hline Share: Social Work Jurnal & VOLUME: 9 & NOMOR: 1 & HALAMAN: 10-19 & $\begin{array}{c}\text { ISSN:2339-0042 (p) } \\
\text { ISSN: 2528-1577 }(e) \\
\text { Doi: 10.24198/share.v9i1.19691 }\end{array}$ \\
\hline
\end{tabular}

kemitraan antara laki-laki dan perempuan. Hubungan kemitraan ini memungkinkan terjadinya hubungan persamaan dan hubungan salirtg menghormati antar jenis kelamin, yang tercermin juga dalam perilaku seksual yang bertanggung jawab. Hubungan yang seimbang dan kemitraan juga berarti dapat menjamin, baik laki-laki maupun perempuan terhadap akses informasi, pendidikan, dan sebagainya.

\section{Konstruksi Media Sosial dalam Kehidupan Masyarakat}

Pengertian dari media sosial menurut Jacka dan Scott (2011, hlm. 98) adalah satu set teknologi yang berbasis web broadcast dimana memungkinkan demokratisasi atas isi, memberikan kesempatan kepada pengguna yang muncul sebagai konsumen dari isi menjadi publisher. Media sosial atau dalam bahasa Inggris 'social media', menurut tata bahasa terdiri dari kata 'social' yang memiliki arti kemasyarakatan atau sebuah interaksi dan 'media' adalah sebuah wadah atau tempat sosial itu sendiri. Menurut Kaplan dan Haenlein (2010, hlm. 53), sosial media sebagai a group of Internet-based applications that build on the ideological and technological foundations of Web 2.0, and that allow the creation and exchange of User Generated Content.

Keberadaan media sosial pada saat ini sangatlah memberikan pengaruh yang kuat terhadap perubahan di dalam masyarakat dan sosial. Pada saat ini media sosial telah membuat ide tentang sebuah 'global village' yang diungkapkan McLuhan (dalam Toivo, 2012, hlm. 57) bahwa dalam era ini manusia telah saling terhubung melalui teknologi komunikasi internet dengan media sosial yang merupakan bagiannya. Ide dari McLuhan tersebut juga senada dengan sebuah istilah yang diungkapkan Friedman (dalam Toivo, 2012, hlm. 66) yaitu 'flat world' di awal abad 21, dimana orang-orang akan saling terhubung melalui komputer dan semakin cepatnya transfer informasi melalui kabel optik. Hal ini dapat dikatakan sebagai revolusi modern dimana hampir dapat menghilangkan batasan antara waktu dan ruang.

Adanya keragaman makna tentang keberadaan media sosial, yang terungkap adalah a) Media sosial dapat menjadi sarana untuk eksistensi diri, menampung pemikiran, melepaskan pikiran, hiburan atau kepuasan, dan membangun jejaring sosial, b) Selain itu media sosial juga menjadi sarana yang sangat efektif untuk sharing, publikasi karya, membentuk komunitas, dan sarana edukasi pemikiran alternatif (kritis), c) Terkait kebebasan, media sosial dimaknai lebih memberikan kebebasan dan melepaskan narasumber dari ikatan nilai atau norma budaya, d) dialogis dan mempertajam pemikiran atau terbiasa menerima kritik, itu dapat terjadi karena media sosial dimaknai sebagai tempat berdebat, berargumen, mempermalukan atau mendapatkan respon atau apresiasi dari pengguna lain (Maryani dan Arifin, 2012, hlm. 7).

Penggunaan media sosial dalam segala kegiatan dapat dikategorikan sebagai perbahan sosial karena mampu memunculkan gejala-gejala perubahan struktur sosial pada masyarakat, mengubah cara lama dengan efisiensi ruang dan waktu. Perubahan sosial berarti adanya perubahan pada struktur dan fungsi masyarakat, perubahan tersebut dapat diketahui dengan adanya modifikasi-modifikasi yang terjadi dalam pola kehidupan manusia (Davis dan Koenig dalam Naszir, 2008, hlm. 78). Hal tersebut diperkuat oleh MacIver (dalam Soekanto dan Sulistiyowati, 2014, hlm. 45) mengatakan bahwa "Perubahanperubahan sosial dikaitkannya sebagai perubahan-perubahan dalam hubungan sosial (social relationships) atau sebagai perubahan terhadap keseimbangan (equilibrium) hubungan sosial”. Perubahan sosial dapat terjadi dalam bentuk material maupun non-material, dan dapat mempengaruhi hubungan sosial dan keseimbangan yang ada di masyarakat sebagai bentuk penyesuaian dan perkembangan pola-pola kehidupan menuju hal yang lebih baik.

Media sosial telah menghapus batasanbatasan dalam bersosialisasi. Hilangnya batas ruang dan waktu, pengguna media sosial dapat berkomunikasi kapanpun dan dimanapun mereka berada. Semakin berkembangnya internet memunculkan pola interaksi yang dapat dilakukan tanpa harus berada dalam ruang dan waktu yang bersamaan. Ragam platform yang terdapat pada media sosial ini, banyak pelajar yang memanfaatkannya sebagai sarana untuk berinteraksi dengan teman, berbagi tugas-tugas sekolah, bermain game, atau sekedar mengisi 


\begin{tabular}{|c|c|c|c|c|}
\hline Share: Social Work Jurnal & VOLUME: 9 & NOMOR: 1 & HALAMAN: 10-19 & $\begin{array}{c}\text { ISSN:2339-0042 (p) } \\
\text { ISSN: 2528-1577 }(e) \\
\text { Doi: 10.24198/share.v9i1.19691 }\end{array}$ \\
\hline
\end{tabular}

waktu luang. Media sosial yang banyak digemari oleh masyarakat khususnya pelajar saat ini menghadirkan berbagai fitur atau fasilitas yang memberikan kesempatan bagi penggunanya untuk dapat mendokumentasikan setiap aspek kehidupannya. Sebagai contoh aplikasi Instagram yang menawarkan kemudahan bagi pengguna untuk berbagi foto dan video yang dilengkapi fitur-fitur tambahan seperti lokasi, live video, boomerang, atau bahkan melakukan percakapan pribadi disertai dengan berbagai macam emoticon menarik.

Penggunaan media sosial juga mengakibatkan berubahnya gaya komunikasi dan karakteristik seseorang seperti membanggakan diri sendiri secara berlebihan atas apa yang dimilikinya. Beberapa orang cenderung menjadi pengguna yang aktif dalam media sosial. bahkan, seringkali mereka terlalu banyak memposting berbagai hal dari mulai kegiatan sehari-hari hingga ke permasalahan yang berbentuk privasi. Hal tersebut dilakukan sebagai ajang utuk menunjukkan keberadaan dirinya kepada dunia luar. Masyarakat yang menjadi pengguna media sosial seringkali berlomba-lomba untuk menampilkan dan membuat branding tentang dirinya kepada dunia luar. Melalui berbagai foto, video, pernyataan yang ada di media sosial, mereka ingin menunjukkan dan mengarahkan pandangan orang lain bahwa mereka adalah seperti yang mereka gambarkan. Seperti yang disebutkan Goffman (dalam Mulyana, 2011, hlm. 156) terkait konsep Dramaturgi, bahwa individu akan menampilkan dirinya sebaik mungkin. Ketika orang-orang berinteraksi, mereka ingin menyajikan suatu gambaran diri yang akan diterima orang lain. Dalam konsep Dramaturgi, kehidupan sosial dimaknai sama seperti pertunjukkan drama dimana terdapat aktor yang memainkan perannya. Akan tetapi, para pelajar yang belum memiliki pengendalian diri yang sempurna dalam mengekspresikan dirinya menjadi rawan terjerumus pada hal-hal yang akan merugikan bahkan mencelakakan dirinya. Sebagai contoh, penggunaan aplikasi Instagram yang belum terkontrol, beberapa pelajar kerap kali mengunggah foto maupun video dengan pakaian yang kurang senonoh dan sopan hanya untuk mendapatkan pujian dan likes dari para followers yang dimilikinya dalam rangka mencari eksistensi dan pengakuan diri.

Kesadaran akan bagaimana hidup dirinya akan dinilai oleh orang lain dalam individu secara tidak sadar meningkat. Perlu disadari bahwa berbagai fitur yang dimiliki oleh media sosial justru membiasakan masyarakat untuk hidup dan mempresentasikan kehidupan yang "likeable" (Jurgenson, 2012, hlm. 86). Seperti halnya dalam pemilihan foto untuk dijadikan profile picture ataupun status yang diperbaharui semuanya didasarkan pada sejauh mana hal tersebut akan disukai oleh orang lain. Kekuatan transformatif yang dihadirkan oleh media sosial ini menjadi salah satu jawaban atas maraknya penggunaan media sosial pada masyarakat saat ini. Media sosial dirasa menjadi salah satu sarana bagi masyarakat untuk mengumpulkan kepercayaan diri serta dukungan dari lingkungannya. Munculnya rasa ketergantungan aktivitas masyarakat dalam berselancar pada jejaring sosial dilatarbelakangi kurangnya pengawasan dan perhatian dari lingkungan terdekat, khususnya keluarga. Sikap dan peran orang tua sangat penting terhadap masalah pengaruh negatif dari media sosial. Akan tetapi, peran masyarakat sebagai komponen pendukung sosialisasi serta pembentuk kepribadian seseorang memiliki andil yang cukup besar.

Dengan kemunculan media sosial sebagai ruang baru untuk berinteraksi, memudahkan mereka dan meningkatkan rasa ingin tahu mereka akan dunia yang lebih luas. Media sosial juga dijadikan sebagai sarana untuk memuaskan hasrat baik yang bersifat positif maupun negatif yang tidak dapat mereka lakukan di dunia nyata. Internet dan perkembangan teknologi informasi merupakan alat yang berpotensi dalam perilaku menyimpang dan merusak dalam kehidupan remaja yang menjadikan mereka sebagai korban secara online (Dowdell, 2011; Staksrud, Olafsson, \& Livingstone, 2013). Berdasarkan kutipan tersebut muncul konstruksi baru dalam perkembangan penggunaan media sosial yaitu remaja yang menggunakan internet dan media sosial telah membuka celah dalam diri mereka sendiri untuk menjadi korban bullying, pelecehan seksual, dan perilaku menyimpang lainnya. 


\section{Realitas Gender dalam Media Sosial Instagram}

Instagram menjadi media sosial favorit karena penggunanya dapat men-sharing kehidupan pribadi melalui bentuk visual. Pada prakteknya, instagram bagaikan sebuah jurnal pribadi yang berbentuk album foto virtual para penggunanya, dimana mereka dapat meng-upload foto apapun yang mereka inginkan, setiap saat kapanpun, menentukan lokasi foto dimanapun, serta menuliskan judul foto apapun. Sehingga konsekuensi didalamnya, media sosial layaknya instagram kerap dimanfaatkan sebagai ajang arena memproduksi realitas yang termediasi (mediated reality) melalui citra visual foto.Jika kita melihat dari aspek sosial, fotografi dapat dilihat dari kecenderungan masyarakat mempergunakan fotografi sebagai fungsi sosial. Penggunaan fotografi disajikan untuk mendefinisikan makna sosial seperti apa yang di definisikan pada gambar tersebut.

Wilayah kebudayaan termasuk media sosial Instagram adalah wilayah otonom yang memiliki bentuk kekuasaan (hegemoni), logika sosial, dan pasar simboliknya sendiri. Instagram sebagai media sosial ternyata merupakan ruang sosial alam dua dimensi yang secara utuh eksis dalam kehidupan kebudayaan media, yaitu ruang-ruang sosial bentukan dimensi kebudayaan. Berawal dari penggunaan media sosial, masyarakat mulai membangun relasi di dunia maya dengan akun pribadinya. Menawarkan pertemanan dan relasi di dunia maya lewat foto sebagai identitas profil. Dengan adanya foto dalam tampilan profil, mereka dengan mudah dapat memilih siapa saja yang akan menjadi teman di dunia maya. Selanjutnya, proses menambah teman di dunia maya tidak terjadi begitu saja. Ada unsur memilih siapa yang akan menjadi teman atau tidak. Dapat dilihat tanpa riset yang mendalam di media sosial, perempuan dengan paras yang dianggap cantik oleh orang banyak akan lebih banyak memiliki teman di dunia maya daripada perempuan yang dianggap buruk wajahnya. Foto yang dipajang sebagai gambar profil merupakan syarat utama yang dapat menentukan bagaimana seseorang akan menjadi populer di dunia maya

Karena sifatnya yang serba visual, media sosial Instagram dimanfaatkan sebagai ‘panggung virtual' untuk menciptakan realitas visual bagi siapapun yang berkecimpung didalamnya. Mereka dengan bebasnya mengekspresikan diri melalui foto agar terlihat dan dikenal menjadi 'siapa', dan bahkan menciptakan dunia yang seperti 'apa'. Seperti halnya ketika kita melihat foto-foto diri yang ditampilkan para informan dalam penelitian ini, yang masing-masing dari mereka memiliki karakter identitas yang berbedabeda. Mereka mencoba untuk mepresentasikan dirinya dengan penampilan semenarik mungkin kehadapan penonton dunia maya agar terlihat dominan ditengah-tengah riuknya beragam identitas virtual masyarakat digital.

Realitas visual yang cenderung dipilih untuk disampaikan merupakan citra yang dapat meningkatkan harga diri individu di dunia maya. Sejauh ini, harga diri atau self-esteem dimengerti sebagai penilaian individu terhadap performa dirinya sendiri, atas kemampuan, keberartian, kehormatan, dan keberhargaan dirinya. Tentunya penilaian tersebut, tidak dapat diukur tanpa melihat pengakuan dari orang-orang sekitar untuk menganalisa : apakah perilaku yang dilakukan sudah sesuai dengan apa yang diidealkan (bagi masyarakat) (Putri, 2016, hlm. 93).

Pada penggunaan media sosial ini ternyata gender adalah satu-satunya variabel demografi yang sangat signifikan berpengaruh dalam penggunaan media sosial, karena ada beberapa perbedaan antara pengguna media sosial laki-laki dan perempuan. Perempuan melakukan empat sampai lima kali lebih banyak waktu untuk menggunakan media sosial dibandingkan dengan pria (Tufekci, 2008, hlm. 24). Sheldon (dalam Sponcil \& Gitimu, 2013, hlm. 352) juga menemukan bahwa perempuan lebih menyukai media sosial untuk menjalin hubungan dengan keluarga dan teman-teman, melewatkan waktu, hiburan, akan tetapi pria lebih menyukai menggunakan media sosial untuk bertemu dengan orang baru. Perempuan yang kuliah juga lebih menyukai menggunakan internet untuk berkomunikasi dan menjalin hubungan, seperti menghubungi teman-teman, keluarga, dan pasangannya (dalam Baym, Zhang, Kunkel, Ledbetter, \& Mei-Chen, 2007, hlm. 749). Pengalaman pendidikan dari pria dan wanita juga merupakan faktor penting yang mempengaruhi penggunaan media sosial. Pria dan wanita yang 


\begin{tabular}{|c|c|c|c|c|}
\hline Share: Social Work Jurnal & VOLUME: 9 & NOMOR: 1 & HALAMAN: 10-19 & $\begin{array}{c}\text { ISSN:2339-0042(p) } \\
\text { ISSN: 2528-1577 (e) } \\
\text { Doi: 10.24198/share.v9i1.19691 }\end{array}$ \\
\hline
\end{tabular}

mendapatkan pendidikan tinggi akan lebih menyukai menggunakan media sosial dalam menunjang aktivitasnya setiap hari (Lenhart et al, 2010, dalam Sponcil \& Gitimu, 2013, hlm. 355).

Menurut riset yang dilakukan oleh firma kemanan digital, Norton, $76 \%$ dari 1.000 responden wanita yang berusia dibawah 30 tahun pernah mengalami pelecehan seksual secara online (Aprillia, 2017). Kekerasan terhadap perempuan tidak hanya terkungkung pada batasan seksual dan psikis, tapi juga penyempitan makna oleh opini publik, sehingga kebebasan untuk menyatakan jati diri terbungkam. Dalam hal penggunaan media sosial Instagram penyematan feminitas sebagai sifat perempuan yang seolah kodrati, kerap berujung pada dikotomi "baik" dan "tidak baik”. Perempuan yang layak, sebagaimana biasa digaungkan oleh gambar-gambar kutipan seksis tersebut, mentok pada mereka yang mau mengabdi pada laki-laki di ruang privat. Kata sifat "cantik" masih tetap diasosiasikan pada potret perempuan berambut panjang lurus, berkulit putih, dan bertubuh langsing atau montok. Memproduksi persepsi bahwa perempuanperempuan lain yang bertubuh gendut, berkulit cokelat, maupun berambut keriting adalah perempuan-perempuan non-primadona.

Banyak pula gambar yang memperlihatkan foto perempuan-perempuan berpakaian terbuka dengan penyertaan kutipan yang menjurus ke stereotipe seksual di dalam media sosial Instagram. Tidak berusaha menyudahi salah kaprah yang telanjur tertanam pada jalan pikir mayoritas masyarakat, banyak yang justru menyatakan bahwa penampilan seronok itulah yang menjadi bakal terjadinya pelecehan fisik. Bentuk-bentuk ajakan untuk chat yang menggoda dan mengganggu merupakan hal yang sudah biasa terjadi dalam konteks penggunaan media sosial. Berdasarkan hasil survey Ditch the Label, Instagram dengan persentase sebesar $42 \%$ merupakan platform media sosial yang penggunanya paling sering menglami cyberbullying. Facebook dengan 37\%, Snapchat dengan $31 \%$, WhatsApp dengan 12\%, Youtube dengan 10\%, dan Twitter dengan 9\% (lihat Chart $1)$.

\section{PENGALAMAN \\ CYBERBULLYING \\ DALAM MEDIA SOSIAL}

- Platform Media Sosial
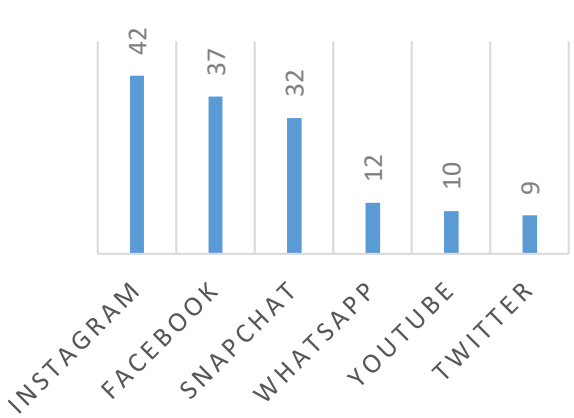

Chart 1. Platform Media Sosial yang Berpotensi Tinggi dalam Cyberbullying

Sumber: The Annual Bullying Survey (2017)

Era digitalisasi dan informasi ini menuntut perempuan untuk dapat memahami dan menggunakan teknologi tersebut dengan bijak. Media sosial yang ada pada saat ini tentu saja mempengaruhi kehidupan kaum perempuan, sebagaimana diketahui ternyata penggunaan media sosial didominasi kaum perempuan. Seorang perempuan boleh saja gemar berpakaian seksi sebagai wujud otonomi atas tubuhnya sendiri. Dan laki-laki yang memahami kesetaraan gender tentu paham bahwa esensi perempuan melebihi anatomi fisik yang dapat memancing birahi. Feminisme bukan lantas mengubah posisi di mana perempuan menyingkirkan laki-laki dari puncak podium. Pemahaman tentang gender diperlukan dalam beberapa kasus diskriminasi yang terjadi dalam Instagram, hal tersebut dapat dijadikan sebagai ideologi yang membebaskan, baik perempuan maupun laki-laki, untuk menentukan hidupnya tanpa merasa direpresi oleh kungkungan-kungkungan sosial.

\section{Kesimpulan}

Meningkatnya kesadaran pengguna akan bagaimana hidup dirinya akan dinilai oleh orang lain telah membuat peningkatan terhadap penggunaan media sosial khususnya Instagram. Perkembangan teknologi komunikasi dan informasi memberikan kemudahan dalam berinteraksi. Kehadiran media sosial sebagai bukti perkembangan teknologi komunikasi 


\begin{tabular}{|c|c|c|c|c|}
\hline Share: Social Work Jurnal & VOLUME: 9 & NOMOR: 1 & HALAMAN: 10-19 & $\begin{array}{c}\text { ISSN:2339-0042 (p) } \\
\text { ISSN: 2528-1577 }(e) \\
\text { Doi: 10.24198/share.v9i1.19691 }\end{array}$ \\
\hline
\end{tabular}

ternyata memberikan pengaruh terhadap perilaku masyarakat.

Rendahnya pengetahuan masyarakat akan pemahaman gender menyebabkan pandangan stereotype masih muncul di dalam penggunaan media sosial Instagram. Sama halnya dalam

\section{Referensi}

Aprillia, I. (2017). Cewek Ini Pernah Mengalami Pelecehan Seksual di Media Sosial, Ini Cara Menghadapinya. cewekbanget.grid.id/Love-Life-And-SexEducation/Cewek-Ini-Pernah-MengalamiPelecehan-Seksual-Di-Media-Sosial-IniCara-Menghadapinya (di akses pada tanggal 03 April 2018, pukul 13.59 WIB).

Baym, N. K., Zhang, Y. B., Kunkel, A., Ledbetter, A., \& Lin, M. C. (2007). Relational quality and media use in interpersonal relationships. New Media \& Society, 9(5), 735-752.

Buss, D. M. (2007). The evolution of human mating. Acta Psychologica Sinica, 39(3), 502-512.

Dedy, M. (2011). Komunikasi Lintas Budaya. Pyt Remaja Rosdakarya, Bandung.

Dowdell, E. B. (2011). Risky Internet behaviors of middle-school students: communication with online strangers and offline contact. CIN: Computers, Informatics, Nursing, 29(6), 352-359.

Echols, M.J \& Shadily, H. (1983). Kamus Inggris Indonesia, Cet. XXI. Jakarta: Gramedia.

Frederikse, M., et.al. (2000). Sex difference in inferior lobule volume in schizophrenia. American Journal of Psychiatry, 157, 422427.

Hacket, L., et.al. (2017). The Annual Bulying Survey 2017. United Kingdom: Ditch The Label.

Hidayat, S. (2011). Sedarmayanti.“. Metodologi Penelitian”. Bandung: Mandar Maju.

Hyde, J. S. (2005). The gender similarities hypothesis. American psychologist, 60(6), 581.

Jacka, J.Mike, Peter R. Scott. (2011) Auditing Social Media; A Governance and Risk Guide. The Institute of Internal Auditors, Reseach Foundation stereotype yang terjadi di dunia nyata maupun di media massa, berbagai pandangan positif maupun negatif lebih banyak diberikan terhadap kaum perempuan. Hal tersebut terjadi karena mayoritas pengguna media sosial Instagram sendiri adalah perempuan.

Jurgenson, N. (2012). When atoms meet bits: Social media, the mobile web and augmented revolution. Future Internet, 4(1), 83-91.

Kaplan, A. M., \& Haenlein, M. (2010). Users of the world, unite! The challenges and opportunities of Social Media. Business horizons, 53(1), 59-68.

Kuswarno, E. (2009). Fenomenologi: metode penelitian komunikasi: konsepsi, pedoman, dan contoh penelitiannya. Widya Padjadjaran.

Lenhart, A., Purcell, K., Smith, A., \& Zickuhr, K. (2010). Social Media \& Mobile Internet Use among Teens and Young Adults. Millennials. Pew internet \& American life project.

Lippa, R. A. (2005). Gender, nature, and nurture. Routledge.

Lips, H.M. (1993). Lips, Sex and Gender: An Introduction. London: Mayfield Publishing Company.

Martin, C. L., Ruble, D. N., \& Szkrybalo, J. (2002). Cognitive theories of early gender development. Psychological bulletin, 128(6), 903.

Maryani, E., \& Arifin, H. S. (2012). Konstruksi Identitas Melalui Media Sosial. Journal of Communication Studies, 1(1), 1-22.

Mulia, M. (2004). Islam menggugat poligami. Gramedia Pustaka Utama.

Nazsir, N. (2008). Teori-Teori Sosiologi. Bandung, Widya Padjajaran.

Nugraha, A., Sudrajat, R.H \& Putri, B.P.S. (2015). Fenomena Meme di Media Sosial: Studi Etnografi Virtual Posting Meme Pada Pengguna Media Sosial Instagram. Jurnal Sosioteknologi, 14(3), 237-245.

Putri, E. (2016). Foto Diri, Representasi Identitas Dan Masyarakat Tontonan Di Media Sosial Instagram. Jurnal Pemikiran Sosiologi, 3(1), 80-97. 


\begin{tabular}{|c|c|c|c|c|}
\hline Share: Social Work Jurnal & VOLUME: 9 & NOMOR: 1 & HALAMAN: 10-19 & $\begin{array}{l}\text { ISSN:2339 -0042 (p) } \\
\text { ISSN: 2528-1577 (e) } \\
\text { Doi: 10.24198/share.v9i1.19691 }\end{array}$ \\
\hline
\end{tabular}

Saguni, F. (2014). Pemberian Stereotype Gender. Jurnal Musawa IAIN Palu, 6(2), 195-224.

Santrock, J.W. (2009). Educational Psycology, (3th ed). Jakarta: Penerbit Salemba Humanika.

Scott, P. R., \& Jacka, J. M. (2011). Auditing social media: A governance and risk guide. John Wiley \& Sons.

Setiadi, E. M., \& Kolip, U. (2011). Pengantar sosiologi: pemahaman fakta dan gejala permasalahaan sosial: teori, applikasi dan pemecahannya. Kencana.

Showalter, E. (1989). Speaking of Gender.

Soekanto, S \& Sulistyowati. (2013). Sosiologi Suatu Pengantar. PT. Raja Grafindo Persada, Jakarta.

Sponcil, M., \& Gitimu, P. (2013). Use of social media by college students: Relationship to communication and self-concept. Journal of Technology Research, 4(1), hlm. 350361.

Staksrud, E., Ólafsson, K., \& Livingstone, S. (2013). Does the use of social networking sites increase children's risk of harm?. Computers in human behavior, 29(1), 40-50.

Toivo, S. (2012). Social Media-The New Power of Political Influence. Centre for European Studies.

Tufekci, Z. (2008). Can you see me now? Audience and disclosure regulation in online social network sites. Bulletin of Science, Technology \& Society, 28(1), 2036.

Umar, N. (1999). Argumen Kesetaraan Gender. Jakarta: Paramadina. 